\title{
On The Front Line: InTEgrated Habitat MAPPIng For Olive Ridley SEA Turtles In The Southeast AtLantiC
}

Stephen K. Pikesley ${ }^{1,2}$, Sara M. Maxwell ${ }^{3}$, Kellie Pendoley ${ }^{4}$ Daniel P. Costa ${ }^{5}$, Michael S. Coyne ${ }^{1,6}$, Angela Formia ${ }^{7}$, Brendan J. Godley ${ }^{1}$, Warren Klein ${ }^{8}$, Junior Makanga-Bahouna ${ }^{9}$, Sheryl Maruca ${ }^{10}$, Solange Ngouessono ${ }^{11}$, Richard J. Parnell ${ }^{9}$, Edgard Pemo-Makaya ${ }^{9}$, \& *Matthew J. Witt ${ }^{2}$

Addresses:

${ }^{1}$ Centre for Ecology and Conservation, University of Exeter. Cornwall. UK

${ }^{2}$ Environment and Sustainability Institute, University of Exeter. Cornwall. UK

${ }^{3}$ Hopkins Marine Station, Stanford University, Pacific Grove CA, USA

${ }^{4}$ Pendoley Environmental Pty Ltd, Booragoon, WA 6154, Australia

${ }^{5}$ Department of Ecology and Evolutionary Biology, University of California Santa Cruz, Santa Cruz CA, USA

${ }^{6}$ SEATURTLE.org, Durham NC, USA

${ }^{7}$ Wildlife Conservation Society, Global Conservation Program, New York, NY, USA

${ }^{8}$ Angola LNG, Soyo, Angloa,

${ }^{9}$ Wildlife Conservation Society, Mayumba National Park, Gabon

${ }^{10}$ Chevron Energy Technology Company, Houston, TX 77042, USA

${ }^{11}$ Agence Nationale des Parcs Nationaux, Libreville, Gabon

* Corresponding author: Matthew J. Witt, M.J.Witt@exeter.ac.uk

Please cite this article in press as: Pikesley, S.K., et al. On the front line: integrated habitat mapping for olive ridley sea turtles in the southeast Atlantic. Diversity Distrib. (2013), DOI: $10.1111 /$ ddi.12118 


\section{ABSTRACT}

Aim Knowledge and understanding of marine vertebrate spatial ecology are required to identify sources of threat and highlight areas for conservation. Olive ridley sea turtles Lepidochelys olivacea are in decline in some regions and data for the Eastern Atlantic are sparse. Here, we seek to describe observed, and potential, post-nesting habitats for this species in the southeast Atlantic. We contextualise these with fisheries catch data to identify areas of potential threat from fisheries interaction for this species.

Location West coast of Africa, southeast Atlantic.

Methods We tracked twenty-one female olive ridley turtles, from two nesting sites, between 2007 and 2010.We used ensemble ecological niche modelling, integrated with knowledge on the physical and biological oceanographic environment, to identify regions where environmental variables exist that may be critical in defining post-nesting habitats for this species. We further integrate fisheries catch data to contextualise potential threat from fisheries.

Results We describe key areas of observed, and potential, olive ridley turtle occurrence at sea, and reveal that there was considerable overlap of these conspecifics, from two distinct nesting regions, within the Angolan Exclusive Economic Zone (EEZ). With the inclusion of fisheries catch data for the region, we highlight areas that have the potential for conflict with fishing activities known to result in bycatch.

Main conclusions This study demonstrates that it is imperative that marine conservation policy recognises the spatial extent of highly migratory species with expansive ranges. It also highlights that deficiencies exist in current knowledge of bycatch, both in gear specificity and in catch per unit effort. With integration of Vessel Monitoring System (VMS) data and those on fisheries catch, knowledge and understanding of bycatch may be improved and this will ultimately facilitate development of appropriate management strategies and long-term sustainability of fisheries and their supporting ecosystems.

Keywords: bycatch, ensemble ecological niche modelling, fisheries, ocean fronts, spatial analysis 


\section{INTRODUCTION}

Successful conservation policy to mitigate anthropogenic impacts to marine vertebrates requires knowledge and understanding of their spatial ecology, particularly when species are highly migratory (Costa et al., 2012). Satellite telemetry has been used to determine oceanographic habitat of a number of migratory marine predators including seabirds, marine mammals, and sharks (Shaffer et al., 2006; Weng et al., 2007; Kappes et al., 2010; Robinson et al., 2012). Furthermore, satellite telemetry has been applied to successfully characterise anthropogenic impacts and/or define management strategies across a diversity of migratory marine vertebrates, including giant manta rays (Manta birostris), grey seals (Halichoerus grypus), albatrosses and pelagic fishes (Matthiopoulos et al., 2004; Hobday et al., 2011; Zydelis et al., 2011; Graham et al., 2012).

Sea turtles are one marine vertebrate that has been the subject of extensive satellite telemetry research (Godley et al., 2008; Hazen et al., 2012). The ongoing use of satellite tracking techniques, coupled with habitat/environmental modelling of sea turtle movements has provided insight into their spatial and temporal ecology (Polovina et al., 2000; Seminoff et al., 2008; Shillinger et al., 2008; Hawkes et al., 2011; Silva et al., 2011; Wingfield et al., 2011), as well as identifying potential areas of threat and highlighting focal areas for conservation (Peckham et al., 2007; Silva et al., 2011; Witt et al., 2011). This increased knowledge has led to a shift away from a generalist migratory model for sea turtle species, to multiple models that recognise post-nesting movements that are flexible (e.g. Hawkes et al., 2006; Arendt et al., 2012a; b), with inter- and intraspecific variability, dichotomous foraging patterns (Schofield $e t$ al., 2010) and strong relationships between patterns of movements and resources (Plotkin, 2010).

Olive ridleys Lepidochelys olivacea (Eschscholtz, 1829) are considered the most abundant of all sea turtles (Abreu-Grobois \& Plotkin, 2008), distributed throughout tropical and subtropical oceans, with nesting beaches occurring within tropical waters (excluding the Gulf of Mexico). Globally, however, there is a net decline in olive ridley populations (Abreu-Grobois \& Plotkin, 2008). Their associated habitat has been described as both coastal (Marcovaldi, 1999; Gopi et al.,2006) and pelagic (Luschi et al., 2003; Abreu-Grobois \& Plotkin, 2008), with diverse populations occupying different marine habitats (Polovina et al., 2004). They are thought to be generalist feeders, including prey such as fish, molluscs and crustaceans, with diet varying among geographic regions (Bjorndal, 1997).

Olive ridley turtles have demonstrated spatial plasticity in their post-nesting movement strategies within populations (McMahon et al., 2007; Whiting et al., 2007; Silva et al., 2011; Rees et al., 2012), as well as in their habitat selection (McMahon et al., 2007; Whiting et al., 2007; Silva et al., 2011). Their migratory movements have also been associated with frontal 
regions of cold core/warm core eddies (Ram et al., 2009). Data for Eastern Atlantic populations of olive ridley turtles are sparse and the status of stocks in this region is unknown due to a lack of long-term quantitative data (Abreu-Grobois \& Plotkin, 2008).

Here we describe post-nesting movements of olive ridley turtles from two different nesting regions from the central African Atlantic coast countries of Gabon and Angola. Our aims are to elucidate facets of the life history of this population and to delineate key areas of occurrence. Utilising available physical and biological oceanographic satellite derived environmental data, together with ensemble ecological niche modelling, we highlight areas where environmental conditions for olive ridley turtles may be most favourable and, with the inclusion of fisheries catch data, analyse the potential for conflict with this possible threat.

\section{METHODS}

Satellite tracking data: collection and processing

Platform transmitter terminals (PTTs) were attached to twenty-eight nesting olive ridley turtles at release sites in southern Gabon and northern Angola. These were Nyafessa (S 3.96, E 11.15; all coordinates given as decimal degrees: WGS 1984) in Mayumba National Park, Gabon ( $n=18)$, and Kwanda Island and Sereia Peninsula near the mouth of the Congo River (S 6.07, E 12.22), north of Soyo, Angola $(n=10)$ over the nesting seasons of 2007/08 (Gabon $n=$ 5), 2008/09 (Gabon $n=13$, Angola $n=8$ ) and 2009/10 (Angola $n=2$ ). PTTs deployed in Gabon were attached in accordance with the method described by Maxwell et al., (2011). PTTs deployed in Angola were attached using a combination of thin layers of epoxy adhesive (Power Fast, Powers Fasteners, NY, USA) and fibreglass cloth. Each PTT was positioned on the central anterior portion of the olive ridley turtle carapace, covering approximately the first and second vertebral scutes. PTTs deployed in Gabon, were either KiwiSat 101 (Gabon: $n=12$, Sirtrack Ltd, Havelck North, New Zealand) or Telonics ST20, Model A1010 (Gabon: $n=6$, Telonics Inc, Mesa, AZ, USA). PTTs deployed in Angola were KiwiSat (Angola: $n=10$, Sirtrack Ltd, New Zealand).

Data transmitted by PTTs were collected using the Argos satellite system (CLS, 2011) and downloaded with the Satellite Tracking and Analysis Tool (STAT) (Coyne \& Godley, 2005). All positions with location accuracy class $Z$ and 0 were removed; a speed and azimuth filter was then applied (Freitas et al., 2008; Witt et al., 2010). All filtering was undertaken in R (R Development Core Team, 2008; R package: argosfilter; Freitas, 2010). Location data were then reduced to best daily locations, herein after referred to as locations, which were positions with the highest quality location class recorded during a $24 \mathrm{~h}$ period. If more than one location was determined with equal quality within the $24 \mathrm{~h}$ period the first received location was 
retained. Where daily locations were missing, we interpolated these linearly, in R ( $\mathrm{R}$ Development Core Team, 2008; R package: trip; Sumner, 2011).

PTT derived location data were imported into the Geographical Information System (GIS) ArcView 9.3 (ESRI, Redlands, CA, USA). To facilitate removal of internesting location data we used a $25 \mathrm{~km}$ radius buffer, extending from each release site, to define the coastal internesting zone for each nesting population of olive ridley turtles. Data within this internesting zone were excluded from this analysis. Seven PTTs (Gabon $n=6$, Angola $n=1$ ), failed to transmit post-nesting movement data, possibly due to premature failure of the transmitter or the attachment (Hays et al., 2007). Twenty-one PTTs (Gabon $n=12$, Angola $n$ =9) transmitted post-nesting movement data for $167 \pm 160$ days (mean \pm 1 SD, range 33-686) (Fig. 1a,b,c, also see Table S1 in Supporting Information).

Location data, with interpolated positions for missing days, were analysed to determine areas of habitat use. We used a polygon sampling grid of $75 \times 75 \mathrm{~km}$ grid squares to sum all spatially coincident locations (Fig. 2a). The same sampling grid was used to determine the number of individual turtles occupying a grid square (Fig. 2b). Non-interpolated locations for all post-nesting movements were analysed to determine monthly latitudinal distributions (Fig. 3a), distance from shore (km) (Fig. 3b), Sea Surface Temperature $\left(\mathrm{SST}^{\circ} \mathrm{C}\right)$ (Fig. 3c) and depth (m) (Fig. 3d) at best daily locations.
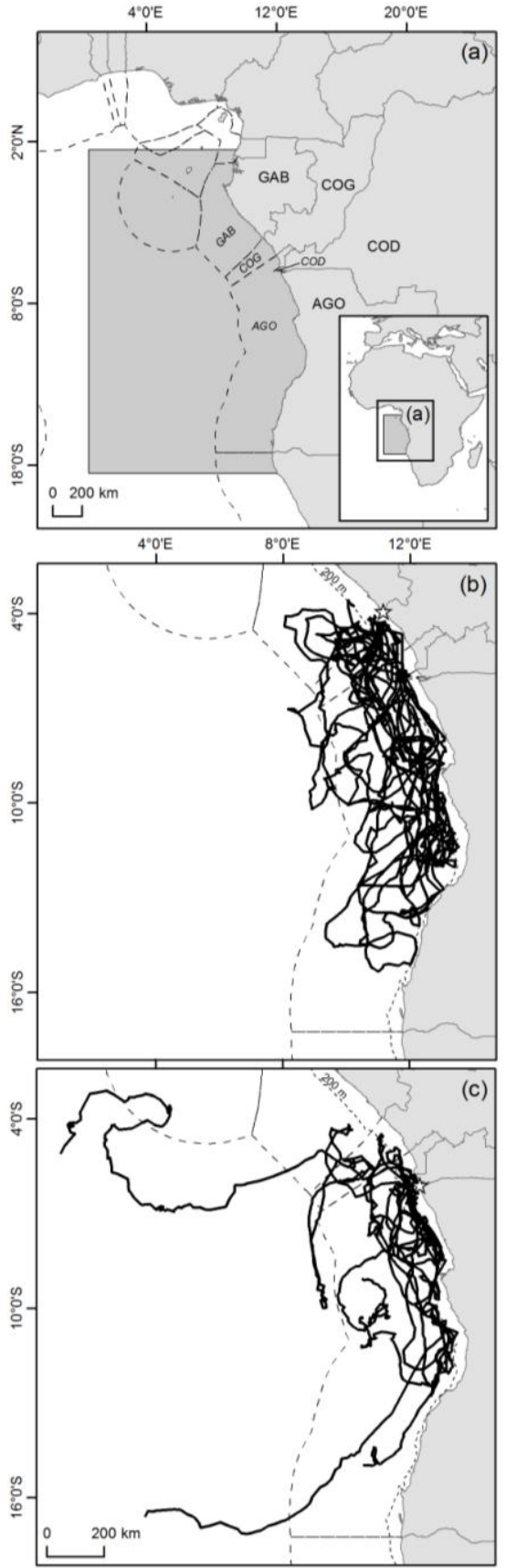

Fig. 1. Study area (a). Post-nesting movements based on best daily locations for satellite tracked olive ridley turtles released from (b) Gabon ( $\mathrm{n}=12)$ and (c) Angola ( $=$ 9). Release locations (open stars), $200 \mathrm{~m}$ continental shelf isobath (broken line). Parts (b) and (c) are drawn to the same spatial resolution. EEZ maritime boundaries (broken line polygon used throughout all maps). Countries and EEZs are labelled as follows: Gabon (GAB), Republic of Congo (COG), the Democratic Republic of the Congo (COD) and Angola (AGO). 

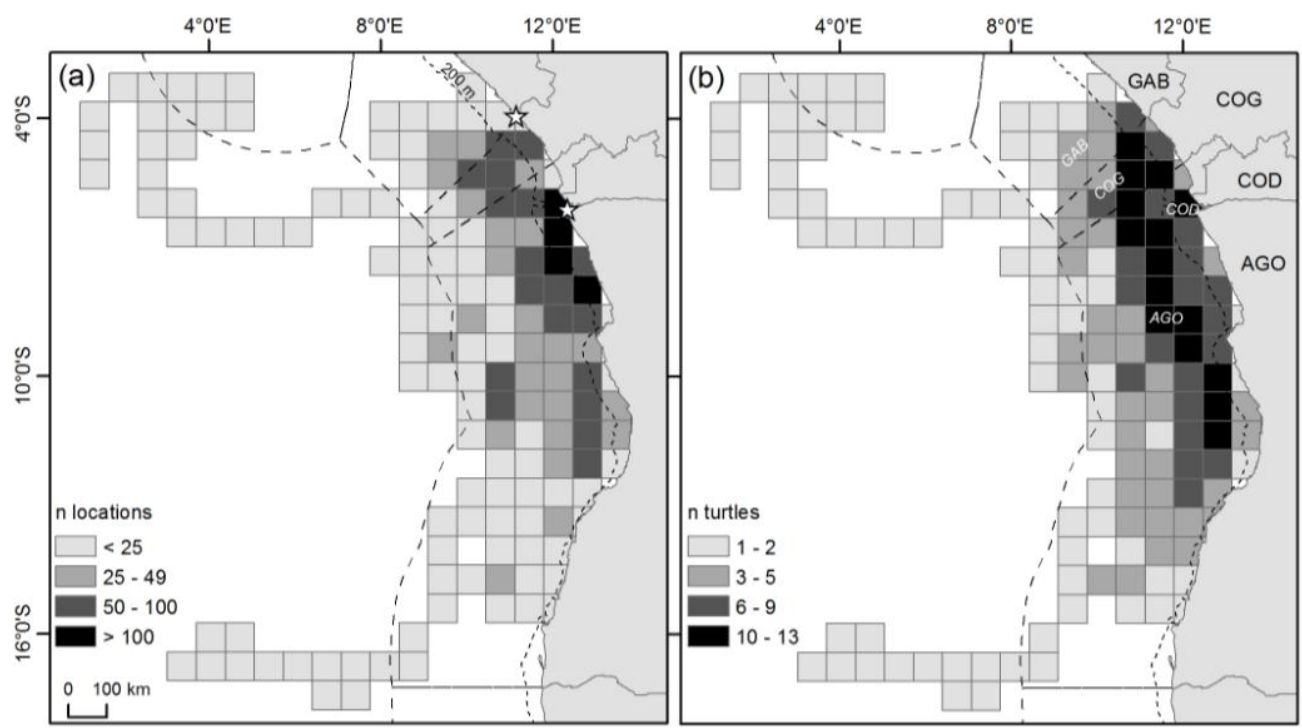

Fig. 2. Density mapping of olive ridley post-nesting movements $(n=21)$ based on interpolated best daily location data. Polygon sampling grid $(75 \times 75 \mathrm{~km})$ of (a) the sum of spatially coincident olive ridley locations and (b) the sum of individuals occupying a grid square. Map features are drawn and labelled in accordance with Fig. 1.
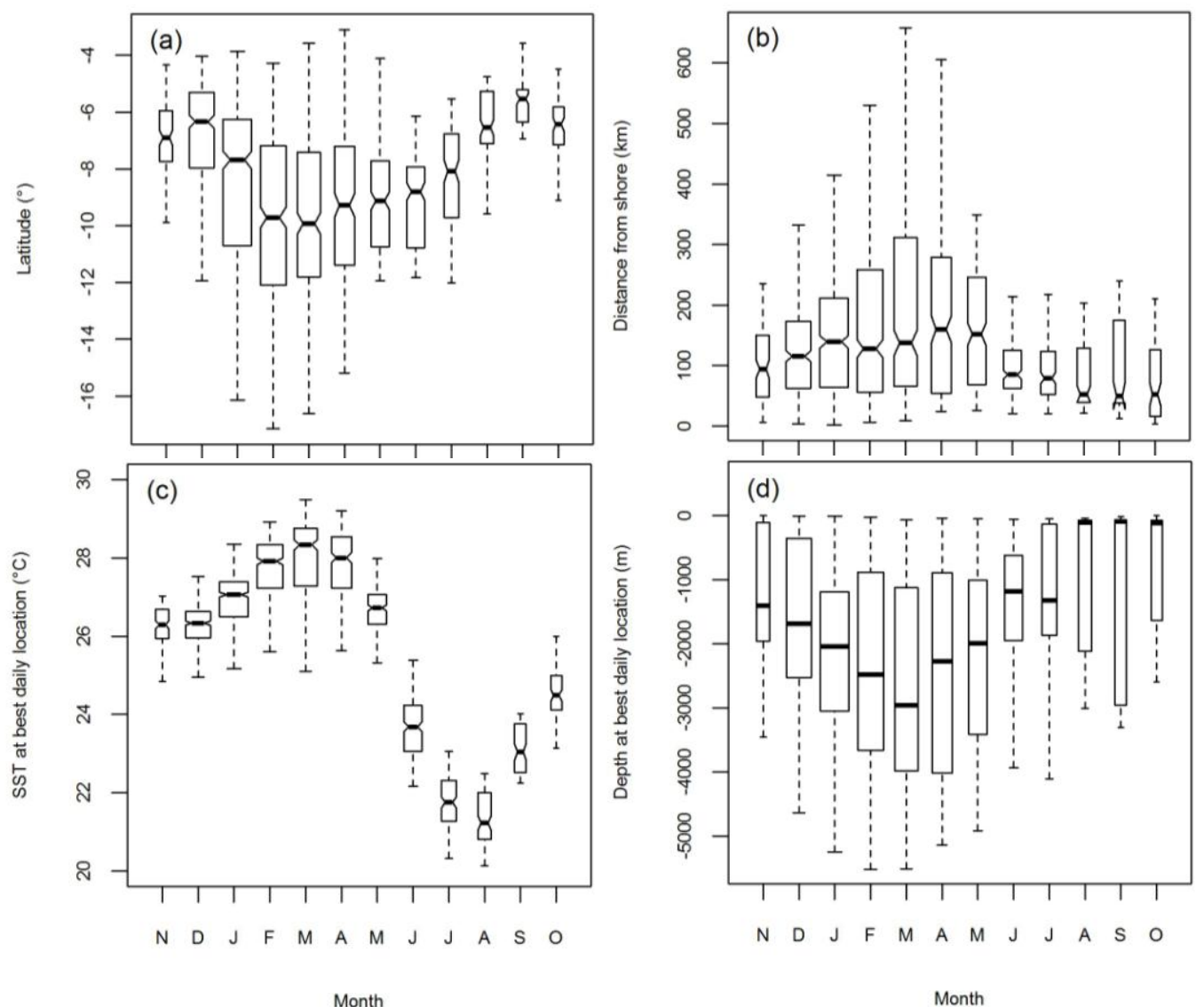

Fig. 3. Median and inter-quartile ranges for (a) latitudinal distribution $\left({ }^{\circ}\right)$, (b) distance from shore (m), (c) monthly SST $\left({ }^{\circ} \mathrm{C}\right)(3$ year mean) and (d) depth $(\mathrm{m})$. Data were derived from non-interpolated, best daily locations, excluding locations within $25 \mathrm{~km}$ internesting zone. Box widths are proportional to the squareroots of the number of observations in the box, outliers are not drawn. Month order was determined by the start of turtle post-nesting activity. 


\section{Habitat modelling}

For our Ecological Niche Models (ENMs), we prescribed the study area to be within latitudes N 1.5, S 18.5 and E 0.5, E 14.0 (sea area: 2.8 million km²) (Fig. 1a). We determined spatially coincident physical and biological environmental data (2008-2010) using Matlab (The MathWorks, Natick, MA, USA) and R (R Development Core Team, 2008; R package: raster; Hijmans \& Etten 2012). These data were: bathymetric depth (m) (www.gebco.net), and monthly averaged daily SST $\left({ }^{\circ} \mathrm{C}\right)$ (http://podaac.jpl.nasa.gov), Sea Surface Height $(\mathrm{SSH})(\mathrm{cm})$ (http://www.aviso.oceanobs.com), Net Primary Production (NPP) (mg C m$\left.{ }^{-2} \mathrm{day}^{-1}\right)$ (http://orca.science.oregonstate.edu) and distance to persistent frontal activity (km). All data were sampled to a $9 \mathrm{~km} \times 9 \mathrm{~km}$ resolution using bilinear interpolation, this being the coarsest resolution of our environmental data. These monthly data, for SST, SSH and NPP, were then averaged into long-term annual products. The resulting data surfaces provided for consistent, near cloud-free, images for the spatial extent of post-nesting movements. To test for correlation within these data a random sample of locations $(n=1000)$ was generated and coincident environmental data extracted for each location. A Spearman's rank correlation test was then calculated for each paired variable.

We used Marine Geospatial Ecological Tools v0.8a43 (MGET; Roberts et al., 2010) to detect oceanic frontal activity for the study area. This software applies the Cayula and Cornillon (1992) Single Image Edge Detection (SIED) algorithm to gridded SST products and produces a binary response raster; a minimum frontal edge detection threshold of $0.5^{\circ} \mathrm{C}$ was used. Level 4 Operational SST and Sea Ice Analysis (OSTIA) data were sourced (http://podaac.jpl.nasa.gov). Daily frontal activity rasters were produced for 2008-2010 and these were then aggregated into yearly rasters with cumulative totals for daily frontal activity. These were in turn averaged into a long-term yearly frontal activity raster. To identify key features while reducing 'clutter' from pixels generated by ephemeral frontal activity, we selected the upper $50 \%$ of pixel positive day values to represent the occurrence of longer-term persistent frontal activity, from this we then determined a long-term yearly raster of distance to persistent frontal activity for the study area.

For our habitat modelling we adopted an ensemble ecological niche modelling approach (Araújo \& New, 2007; Rangel \& Loyola, 2012). We used the Generalised Additive Model (GAM), Multivariate Adaptive Regression Splines (MARS) and MaxEnt modelling algorithms within the biomod2 package (R Development Core Team, 2008; R package: biomod2; Thuiller et al., 2013) to produce ENMs to identify areas where environmental conditions for olive ridley turtles were most favourable (Fig. 4). Our response variable was binary, either 'presence' described by our non-interpolated location data or randomly generated 'pseudo absences'; these background data characterise the 'available' environment parameters within the study area. 

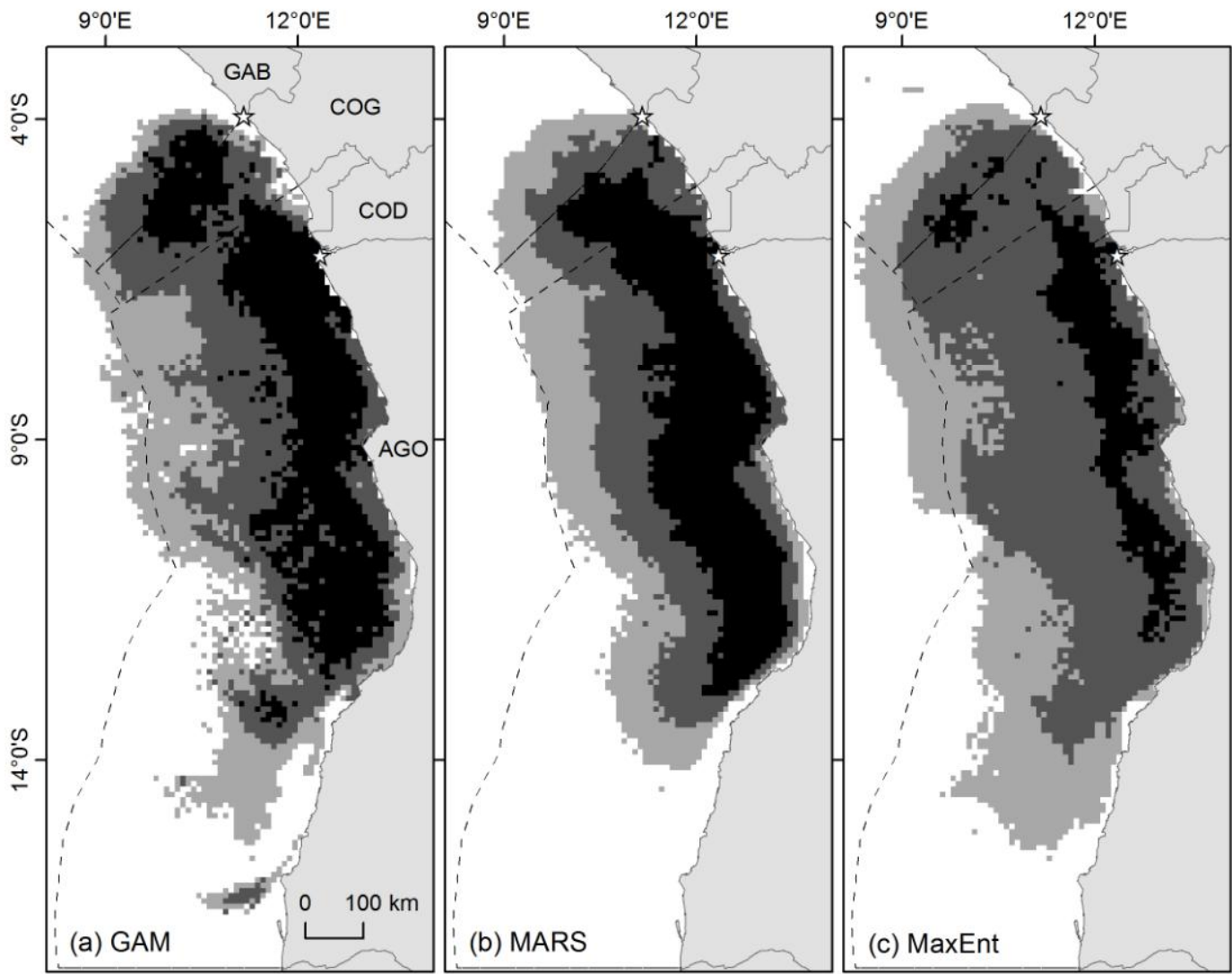

Fig. 4. Ecological Niche Models using the (a) Generalised Additive Model (GAM), (b) Multivariate Adaptive Regression Splines (MARS) and (c) MaxEnt modelling algorithms within the biomod2 package (R Development Core Team, 2008; R package: biomod2; Thuiller et al., 2013). ENMs were run with noninterpolated location data and with the environmental variables of depth, SST, SSH, NPP and proximity to oceanic frontal activity, using long-term averaged yearly products. These ENMs describe the relative suitability of oceanic habitat, scaled between 0 and 1 , where 0.5 represents areas of typical habitat suitability and are represented by monochrome shading as follows: white $<0.5$, mid grey $0.5-0.75$, dark grey 0.75-0.9 and black > 0.9. Countries are labelled as follows: Gabon (GAB), Republic of Congo (COG), the Democratic Republic of the Congo (COD) and Angola (AGO).

ENMs were run with the environmental variables of depth, SST, SSH, NPP and proximity to frontal activity, using long-term averaged yearly products. All models were run using 10 fold cross validation with a 75/25\% random spilt of the location data for calibration, and model testing respectively. All other modelling parameters are detailed in Table S2.

Model performance was evaluated using five metrics. 1) Area Under (the receiver operating characteristic) Curve (AUC); a measure of the ratio of true positives out of the positives vs. the ratio of false positives out of the negatives. 2) Cohen's Kappa (Heidke skill score) (KAPPA) and 3) True Skill Statistic (TSS): a measure of accuracy relative to that of random chance. 4) Success Ratio (SR): the fraction of the true positives that were correct and 5) Accuracy: the fraction of the predictions (true and false) that were correct (Thuiller et al., 2009; Thuiller et al., 2013). All evaluation metrics were scaled to the range 0 to 1 . This enabled us to 

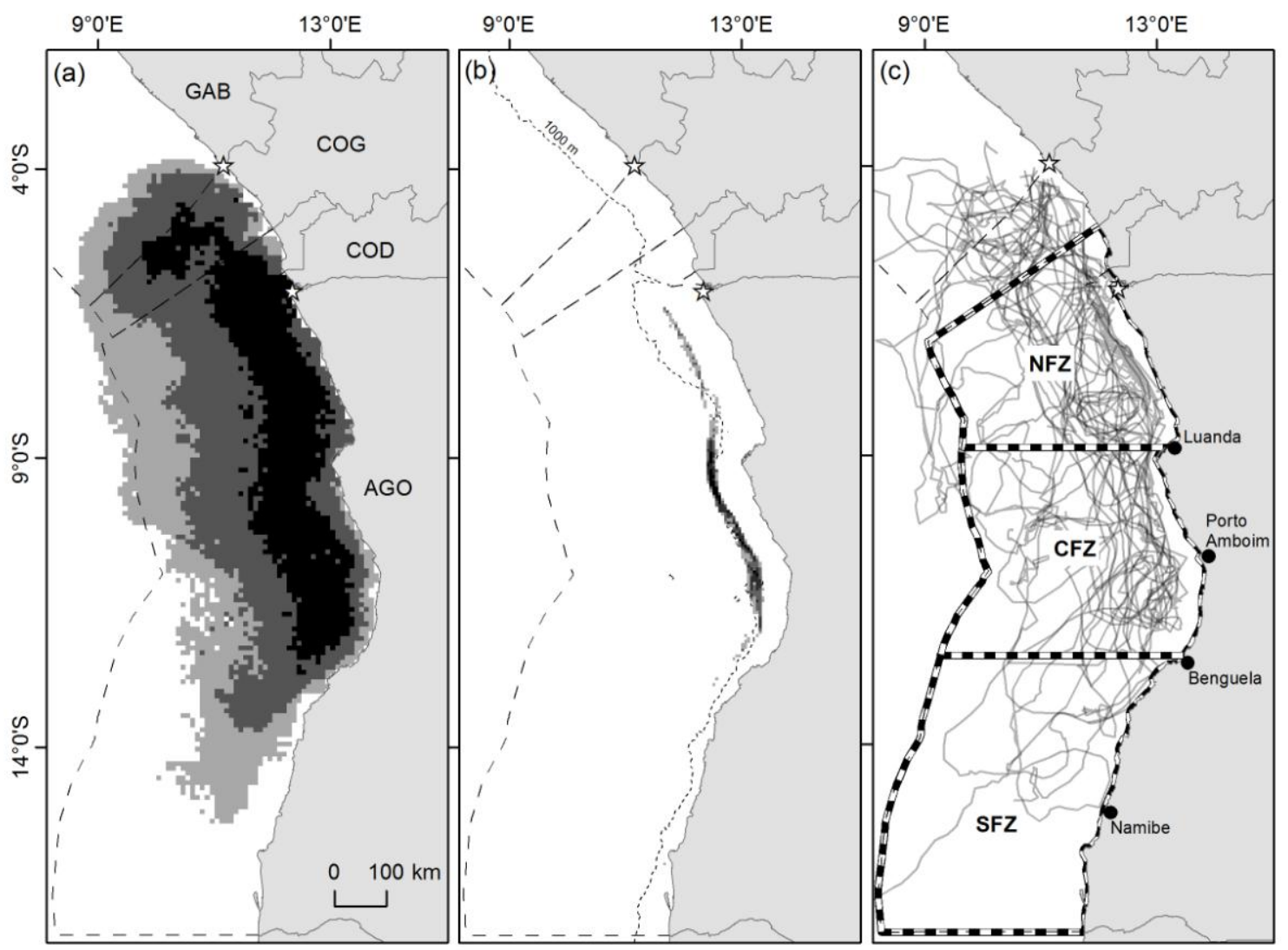

Fig. 5. (a) Ensemble ecological niche model for post-nesting movements based on best daily locations for olive ridley turtles $(n=21)$, depth and the long term yearly environmental variables of SST, SSH, NPP and proximity to oceanic frontal activity. The relative suitability of oceanic habitat is scaled between 0 and 1 , where 0.5 represents areas of typical habitat suitability, 0 represents lowest suitability and 1 highest suitability, is represented by monochrome shading as follows: white $<0.5$, mid grey $0.5-0.75$, dark grey 0.75-0.9 and black > 0.9. (b) Shows the location and spatial extent of longer-term persistent oceanic frontal activity, the $1000 \mathrm{~m}$ isobath is represented as a broken line. (c) Cumulative yearly post-nesting movements based on best daily locations satellite tracking data for all olive ridley turtles $(n=21)$ with key fishing ports labelled. The northern (NFZ), central (CFZ) and southern (SFZ) Angolan fisheries zones are shown as polygons with heavy weight broken black lines.

evaluate model uncertainties within and between models (Table S2). As all models performed with similar accuracy, these ENM projected surfaces were then combined to form an ensemble projection using an un-weighted average across models. This ensemble ENM described the relative suitability of oceanic habitat, scaled between 0 and 1 , where 0.5 represents areas of typical habitat suitability, 0 represents lowest suitability and 1 indicates greatest suitability (Fig. 5a).

The relative importance of the contribution to the model of each environmental variable, was calculated using a randomisation process. This procedure calculated the correlation between a prediction using all environmental variables and a prediction where the independent variable being assessed was randomly re-ordered. If the correlation was high the 
variable in question was considered unimportant for the model and conversely, if low, important. A mean correlation coefficient for each environmental variable was then calculated over multiple runs. This was repeated for each environmental variable (Thuiller et al., 2009 ). The calculation of the relative importance was made by subtracting these mean correlation coefficients from 1 .

\section{Fisheries Data}

To contextualise our observed and modelled areas of habitat use with fisheries activity, we obtained cumulative tuna and billfish yearly catch data (1995-2009) for the study area (FAO, 2012a) by FAO Major Fishing Area Cell (FAO, 2012b). As some of these area cells contained land masses we apportioned these data for the cell's coincident sea area (tonnes $/ \mathrm{km}^{2}$ ); these were then apportioned by the coincident area of the respective Angolan Exclusive Economic Zone (EEZ) fishing zone and by gear type (FAO, 2007) (Fig. 6a,b, Table S3 \& S4). This was then compared with the spatial distribution of the turtles' observed and potential habitat.
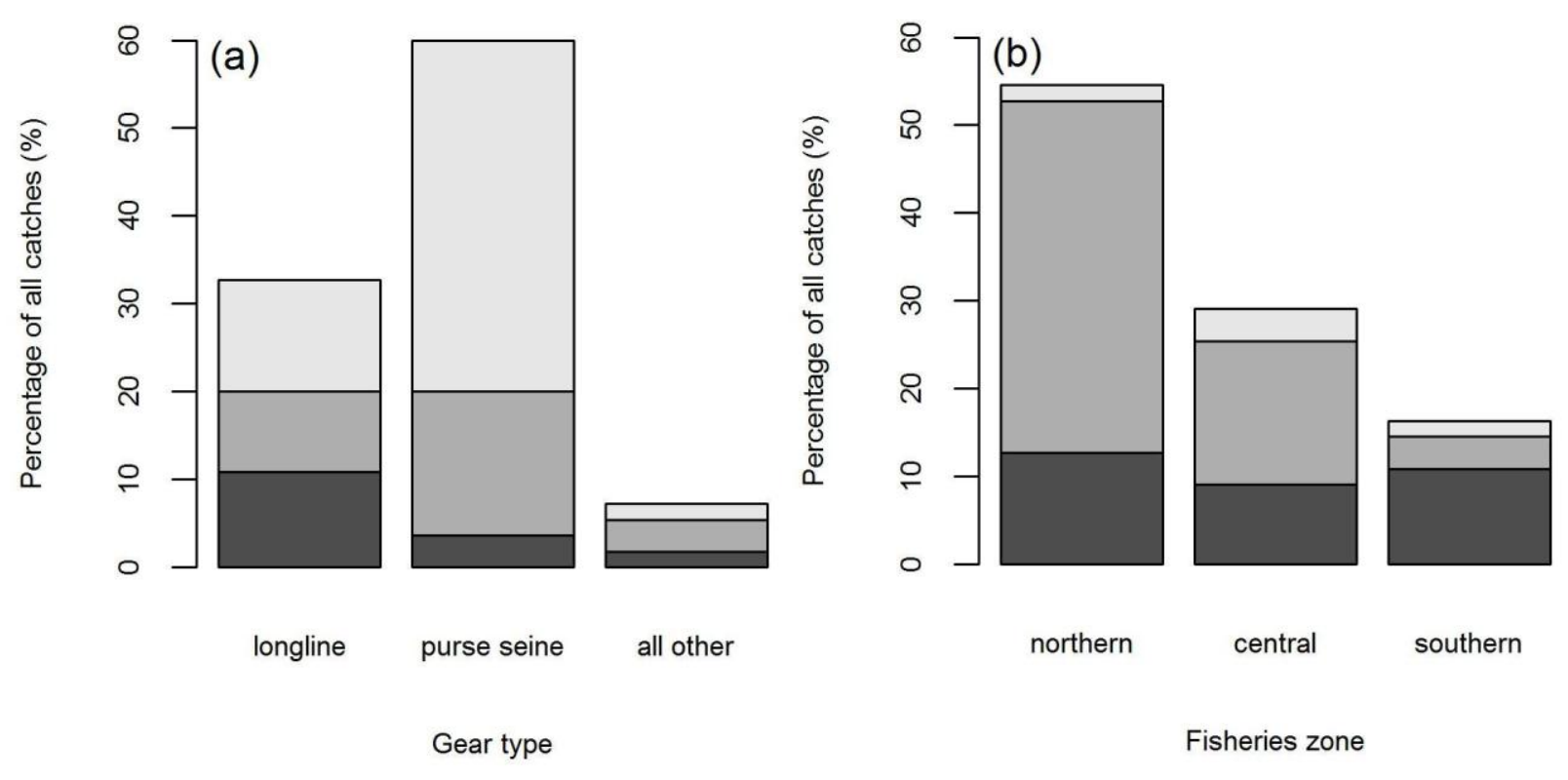

Fig. 6. Cumulative tuna and billfish catch data (1995-2009) by Fishing Area Cell at $5^{\circ}$ by $5^{\circ}$ resolution, apportioned by the cell's coincident sea area, as a percentage of all data, by (a) gear type and fisheries zone, Angolan EEZ fisheries zones identified as: northern (light grey), central (mid grey) and southern (dark grey), and by (b) Angolan EEZ fisheries zone and gear type, gear type is identified as: longline (dark grey), purse seine (mid grey) and all other gear type (light grey). 


\section{RESULTS}

\section{Satellite tracking}

Post-nesting olive ridley turtles $(n=21)$ were satellite tracked for $167 \pm 160$ days (mean $\pm 1 \mathrm{SD}$, range 33-686) with tracked distances (minimum straight-line) ranging between 694 and $9,182 \mathrm{~km}$. There was no significant difference in the median post-nesting tracking durations between release sites (Mann-Whitney, $\mathrm{p}=0.943)($ Gabon $n=12$; median $116 \mathrm{~d}$, Angola $n=9$; median $=111 \mathrm{~d}$ ). Throughout their post-nesting movements, nineteen olive ridley turtles (Gabon $n=12$, Angola $n=7$ ) occupied oceanic waters, primarily within the 200 nautical mile EEZs of Gabon, Republic of Congo, Democratic Republic of Congo and Angola (Fig. 1b,c). The remaining two turtles (Table S1, IDs: T and U) both from the Angolan release site (the only turtles tagged during the 2009/10 nesting season) departed the internesting coastal zone in November 2009 and moved into oceanic waters outside the EEZs, with the most northerly tracked turtle's movements being associated with an area of seamounts (Fig. 1c). Of the nineteen turtles that occupied oceanic EEZ waters, eighteen made post-nesting movements that progressed in a southerly direction (Gabon $n=11$, Angola $n=7$ ), the remaining turtle (Table S1, ID: B) stayed in close proximity to the internesting zone for the period of its PTT transmissions ( $\mathrm{n}=197$ days).

Greatest habitat use occurred within approximately $200 \mathrm{~km}$ of the coast, off the continental shelf, in depths $<2,000 \mathrm{~m}$, with highest densities of olive ridley locations consistently occurring within the Angolan EEZ (Fig. 2a,b). Turtles occupied EEZ waters as follows: Angola 77\% of all locations, Republic of Congo 9\%, Gabon 5\%, Democratic Republic of Congo 1\% and Equatorial Guinea 1\%; $7 \%$ of all locations fell outside of EEZ waters.

Analysis of monthly latitudinal distributions showed that there was, in general, a progressive southerly movement in distribution post-nesting (December to February), followed by a slower northerly contraction (March to August) (Figs 3a, Fig. S1). There was evidence for an offshore expansion in the spatial distribution of turtle locations from the coast January through to May associated with an increase in depth (Figs 3b,d, Fig. S1); sea surface temperatures at best daily locations were also at their greatest throughout these months (Fig. $3 c)$.

\section{Habitat modelling}

Ensemble ecological niche modelling identified that a large majority of Angolan EEZ waters together with a small area of Gabonese/Republic of Congo and Democratic Republic of Congo EEZ waters potentially hosted the most suitable year round environmental conditions for 
olive ridley turtles. Areas with the highest average probability (>0.9) that environmental conditions were favourable, predominantly occurred within $150 \mathrm{~km}$ of the Angolan coast in depths of $1290 \mathrm{~m}$ (638 to $1822 \mathrm{~m}$ ) (median and inter-quartile range), with much of the area straddling the $1000 \mathrm{~m}$ isobath (Fig. 5a). Proximity to persistent fronts was the most important contributory variable across all models (Table S5). No one model appreciably outperformed the others on comparison of individual model evaluation scores or on comparison of overall averaged evaluation scores (GAM: 0.885 (SD 0.007), MARS: 0.880 (SD 0.010), MaxEnt: 0.882 (SD 0.005)) (Table S2). The environmental variables of depth and NPP, as well as SST and $\mathrm{SSH}$, were highly correlated ( $\mathrm{rho}=0.76, \mathrm{p}<0.001$ and rho $=0.84, \mathrm{p}<0.001$ respectively); frontal activity was also associated with shallower depths and areas of higher NPP than was otherwise typically present across the study area (Fig. S2a,b).

\section{Fisheries Data}

Fisheries catch data and associated gear type varied across the Angolan EEZ fisheries zones. Landings were greatest from the northern zone (55\% of all landings), compared with central (29\%) and southern (16\%) zones with purse seine netting accounting for $60 \%$ of all landings (40\% from the northern zone) compared with $33 \%$ for longlines and $7 \%$ attributable to all other gear (FAO, 2012a,b) (Fig. 6a,b, Table S4).

\section{DISCUSSION}

As far as we are aware, this is the first time ensemble models have been applied to satellite tracking data for marine species and so some caution should be applied with interpreting results. A range of issues have been identified with the analysis of telemetry data associated with habitat modelling and a number of potential solutions proposed (Aarts et al., 2008). We attempted to overcome limitations within our data through a sample size large enough that animal movement converged upon a single foraging region, and by including only a single location per day. Furthermore, with the ensemble model approach, we were able to create a single model that integrated the strengths of multiple models and evaluation metrics simultaneously. Notwithstanding these caveats, the concordance across modelling methodologies adds confidence to our findings and the management recommendations that we make as a result.

East Atlantic olive ridley turtles are understudied (Abreu-Grobois \& Plotkin, 2008). Post-nesting movement studies from other sites have described plasticity in post-nesting movement strategies within populations (McMahon et al., 2007; Whiting et al., 2007; Plotkin, 2010; Silva et al., 2011; Rees et al., 2012). These include spatially discordant movements 
within populations; individuals displaying local residency and migratory movements (e.g. Rees et al., 2012), as well as flexibility in habitat use; coastal, continental shelf and deep water (e.g. McMahon et al., 2007; Whiting et al., 2007).

In this study, with the exception of one individual, turtles made expansive migratory movements. Despite occasional movements of up to $200 \mathrm{~km}$ offshore, this 'resident' turtle remained in close proximity to the internesting coastal zone, for the 197 days of transmission, generally within $100 \mathrm{~km}$ of the nesting beach. Two turtles (the only individuals tagged from the $2009 / 10$ nesting period) migrated to deep and offshore oceanic waters (3,000 to 5,000 m). The most northerly of these two turtles was tracked west from the internesting beach, and was associated with seamounts. The second turtle made similar southerly movements to those seen for the 2008/9 nesting cohort, but then continued in a south-westerly direction and left the Angolan EEZ. This may represent differences in dispersal strategies between years, as has been shown for loggerhead turtles (Hawkes et al., 2006) or specialised foraging strategies of a few individuals as has been seen in other predator species (Maxwell et al., 2012), but the sample size is small.

The main assemblage of eighteen turtles made post-nesting movements that progressed in a southerly direction and were focused within the EEZs of Gabon, Congo and Angola. Mapping highlighted significant habitat use by these turtles in waters $200-2000 \mathrm{~m}$ deep, occurring within $200 \mathrm{~km}$ of the coast, with individuals from two distinct nesting sites converging in Angolan waters. Ensemble ecological niche modelling indicated that suitable environmental conditions for olive ridleys was most likely to occur within the northern and central section of the Angolan EEZ. The most suitable environmental conditions being closely associated with coastal areas of persistent frontal activity within $150 \mathrm{~km}$ of the coast and in depths of approximately $1000 \mathrm{~m}$.

In addition to the long-term persistent frontal activity identified within this study, the coastal waters of the Angolan EEZ benefit from the convergence of the warm Angolan current from the north and the cool Benguela current from the south; this produces the AngolaBenguela front (Peterson \& Stramma, 1991). This frontal activity brings associated increased productivity for marine ecosystems and benefits Angolan fisheries. These fisheries are described by three zones; the northern, central and southern fisheries zones (Fig. 5c, Table S3) (FAO, 2007). Longline, purse seine, seine, trawl and gillnet gear types are deployed throughout all fisheries zones (Table S3). The industrial fishery comprises of national and foreign-flagged vessels, which operate through leases or in joint venture with Angolan enterprises. These primarily operate from four ports; Luanda, Porto Amboim, Benguela and Namibe, (Fig. 5c) (FAO, 2007). In 2002, fisheries in this region had an estimated total catch of 170,000 t (Metric Tonnes) from approximately 200 vessels, mainly using purse-seine and trawl gear types (FAO, 2007). However, neither catch nor gear type was distributed evenly across the region. Artisanal 
fisheries also contribute a significant fisheries effort. In 2002, it was estimated that 3,000 to 4,500 vessels, operating from 102 regular sites along the length of the coast, landed in excess of $100,000 \mathrm{t}$ (FAO, 2007), though significantly, the spatial distribution of these fisheries is almost entirely unknown.

Bycatch is a significant threat to most sea turtle species (Lewison et al. 2013). However, there is a paucity of reported data for sea turtle bycatch (Wallace et al., 2010). Quantification of impact is hampered by gear specificity and operational characteristics (Casale et al., 2007). Bycatch is perceived as the greatest threat to Eastern Atlantic populations of olive ridley turtles (Donlan et al., 2010). Olive ridleys elsewhere can be negatively impacted by coastal and offshore trawl (Pandav et al., 1997; Gopi et al., 2006), purse seine (Abreu-Grobois \& Plotkin, 2008; Amandè et al., 2010) and longline fisheries (Work \& Balazs, 2002; Polovina et al., 2003; Carranza et al., 2006). Turtles are also at a high risk of bycatch from small-scale, artisanal fisheries near to nesting or foraging grounds (Parnell et al., 2007; Peckham et al., 2007; Weir et al., 2007; Maxwell et al., 2011); olive ridleys have shown flexible internesting behaviour involving extensive travelling distances (Hamel et al.,2008) which may increase exposure to bycatch.

Given the spatial overlap of olive ridley at-sea distribution and fisheries effort this species is at risk from negative interactions with both small-scale and industrial fisheries once they leave the nesting grounds. This may be particularly so within the northern and central Angolan fisheries zones. Increased knowledge of fishing effort and associated levels of sea turtle bycatch, attributable to gear types within the Angolan EEZ, would help assist the formulation of sustainable and effective bycatch management strategies. Further integration of Vessel Monitoring System (VMS) data (Witt \& Godley, 2007) together with gear specificity would quantify gear specific fishing effort (e.g. Lee et al., 2010) and observer-based programmes could provide gear specific bycatch data (Lewison et al., 2004; Finkbeiner et al., 2011). These measures are likely to increase our understanding of the potential for impact from industrial fisheries. However, impacts from artisanal fisheries are likely to remain under assessed (Lewison et al., 2004). This is of considerable concern, as increased understanding of the importance of bycatch, and the spatial distribution of small-scale artisanal fisheries appears to be critical for the management of both catch species and those caught as bycatch (Stewart et al., 2010).

Gear modifications and adjustment to fisheries practice may be appropriate to some fisheries (Gilman et al., 2009) (Table S6). Spatio-temporal gear and effort restrictions may also help mitigate impacts in seasonal olive ridley 'hotspot' areas, as may identification and establishment of appropriately sited Marine Protected Areas (MPAs), however, displacement of fishing effort from these areas may increase bycatch of turtles and/or other species of concern in other areas (Abbott \& Haynie, 2012). Addressing bycatch in small-scale and artisanal fisheries 
may be more complex as fishermen are more constrained to regions near to their home, and may be operating on a much smaller profit margin, making gear switches more difficult. Promotion of bycatch release programmes may be an option in some fisheries (Ferraro \& Gjertsen, 2009), and may be particularly appropriate in smaller scale fisheries. Advancement of ecosystem based fisheries management schemes that promote responsible and sustainable practice may also be a way forward for artisanal fisheries (Casale, 2011). The implementation of any measures, must also consider the social and economic impact to the industry, particularly to subsistence artisanal fisheries (Weir et al., 2007; Lewison et al., 2013).

Olive ridleys nest throughout the west coast of Africa, between Guinea Bissau and Angola, including many of the region's islands (Fretey, 2000). This study provides an insight into the understudied post-nesting movements of olive ridley turtles, and represents the largest satellite tracked analysis of olive ridley turtles from the southeast Atlantic to date. While modelling the distribution of a far ranging species from two regions, this analysis highlights the coincident habitat use of olive ridley turtles, in relation to favourable areas. Additional tracking of olive ridleys from other nesting locations may determine the importance of these areas for other southeast Atlantic individuals. Given the variability in the two animals tracked in 20092010, it is feasible that not all movement patterns have been captured by our study animals and additional years may reveal different strategies and habitats. This study also highlights the potential for conflict with fishing activities. Increased knowledge of gear specific fisheries effort and bycatch, within the Angolan, Congolese, and Gabonese EEZs, would help facilitate an integrated approach, both within and between countries, to formulate a more dynamic and effective conservation policy.

\section{ACKNOWLEDGEMENTS}

This study was supported by the Darwin Initiative and NERC. Gabonese tracking work was supported by the Disney Worldwide Conservation Fund (STO-08-01) and the Tagging of Pacific Predators Project, with additional support from the Darwin Initiative, Centre for the Dynamics and Evolution of the Land-Sea Interface, Friends of Long Marine Laboratory, Society for the Study of Amphibians and Reptiles, the Marilyn Davis Memorial Scholarship, the UCSC Graduate Student Association, Square's Landscaping and Kitchen Gardens, Inc. SMM was supported by fellowships from the National Science Foundation, University of California Santa Cruz, Achievement Awards for College Scientists and Steve Blank. Sea turtle nest monitoring in Gabon was coordinated through the Gabon Sea Turtle Partnership, with funding from the Marine Turtle Conservation Fund (United States Fish and Wildlife Service, U.S. Department of the Interior). We thank A. Mavoungou Djimbi Alain, S. Zassi, E. Ibouanga Amos, L. Schonkneckt and M. Markovina for field support and Wildlife Conservation Society 
staff, especially Q. Makaya Pambou, for logistical support. Angolan tracking work was funded by the Angola LNG project (Kwanda Base, Soyo) with logistical support provided by Chevron USA. The authors acknowledge the constructive input from three anonymous referees, the Editor-in-Chief and the Associate Editor.

\section{References}

Aarts, G., MacKenzie, M., McConnell, B., Fedak, M. \& Matthiopoulos, J. (2008) Estimating space-use and habitat preference from wildlife telemetry data. Ecography, 31, 140-160

Abbott, J.K. \& Haynie, A.C. (2012) What are we protecting? Fisher behavior and the unintended consequences of spatial closures as a fishery management tool. Ecological Applications, 22, $762-777$.

Abreu-Grobois, A. \& Plotkin, P. (2008) Lepidochelys olivacea. IUCN 2011. IUCN Red List of Threatened Species. Version 2011.2. Available from www.iucnredlist.org. Accessed 23 April 2012.

Amandè, M.J., Ariz, J., Chassot, E., De Molina, A.D., Gaertner, D., Murua, H., Pianet, R., Ruiz, J. \& Chavance, P. (2010) Bycatch of the European purse seine tuna fishery in the Atlantic Ocean for the 2003-2007 period. Aquatic Living Resources, 23, 353-362.

Araújo, M.B. \& New, M. (2007) Ensemble forecasting of species distributions. Trends in Ecology \& Evolution, 22, 42-47.

Arendt, M.D., Segars, A.L., Byrd, J.I., Boynton, J., Schwenter, J.A., Whitaker, J.D. \& Parker, L. (2012a) Migration, distribution, and diving behavior of adult male loggerhead sea turtles (Caretta caretta) following dispersal from a major breeding aggregation in the Western North Atlantic. Marine biology, 159, 113-125.

Arendt, M.D., Segars, A.L., Byrd, J.I., Boynton, J., Whitaker, J.D., Parker, L., Owens, D.W., Blanvillain, G., Quattro, J.M. \& Roberts, M.A. (2012b) Distributional patterns of adult male loggerhead sea turtles (Caretta caretta) in the vicinity of Cape Canaveral, Florida, USA during and after a major annual breeding aggregation. Marine biology, 159, 101-112.

Bjorndal, K.A. (1997) Foraging ecology and nutrition of sea turtles. Lutz PJ, Musick JA (eds) The biology of sea turtles. CRC Press, Boca Raton, FL, p 199-231.

Carranza, A., Domingo, A. \& Estrades, A. (2006) Pelagic longlines: a threat to sea turtles in the equatorial eastern Atlantic. Biological Conservation, 131, 52-57.

Casale, P. (2011) Sea turtle by-catch in the Mediterranean. Fish and Fisheries, 12, 299-316.

Casale, P., Cattarino, L., Freggi, D., Rocco, M. \& Argano, R. (2007) Incidental catch of marine turtles by Italian trawlers and longliners in the central Mediterranean. Aquatic Conservation: Marine and Freshwater Ecosystems, 17, 686-701.

Cayula, J.F. \& Cornillon, P. (1992) Edge detection algorithm for SST images. Journal of Atmospheric and Oceanic Technology, 9, 67-80.

CLS (2011) Argos user's manual. http://www.argossystem.org/documents/userarea/argos_manual_en.pdf. Accessed 16 June 2012

Costa, D.P., Breed, G.A. \& Robinson, P.W. (2012) New insights in pelagic migrations: Implications for ecology and conservation. Annual Review of Ecology and Systematics, 43, 73-96.

Coyne, M.S. \& Godley, B.J. (2005) Satellite Tracking and Analysis Tool(STAT): an integrated system for archiving, analyzing and mapping animal tracking data. Marine Ecology Progress Series, 301, 1-7.

Donlan, C., Wingfield, D.K., Crowder, L.B. \& Wilcox, C. (2010) Using expert opinion surveys to rank threats to endangered species: A case study with sea turtles. Conservation Biology, 24, 15861595.

FAO (2007) Fishery profile: Angola - National Fishery Sector Overview. Available from http://www.fao.org/fishery/countrysector/FI-CP_AO/en Accessed 15 May 2012 
FAO (2012a) Atlas of Tuna and Billfish Catches. Available from http://www.fao.org/figis/geoserver/tunaatlas/ Accessed 10 July 2012

FAO (2012b) Atlas of Tuna and Billfish Catches. Available from http://www.fao.org/fishery/cwp/handbook/G/en Accessed 10 July 2012

Ferraro, P.J. \& Gjertsen, H. (2009) A Global Review of Incentive Payments for Sea Turtle Conservation. Chelonian Conservation and Biology, 8, 48-56.

Finkbeiner, E.M., Wallace, B.P., Moore, J.E., Lewison, R.L., Crowder, L.B. \& Read, A.J. (2011) Cumulative estimates of sea turtle bycatch and mortality in USA fisheries between 1990 and 2007. Biological Conservation, 144, 2719-2727.

Freitas, C. (2010) argosfilter: Argos locations filter. R package version 0.62.

Freitas, C., Lydersen, C., Fedak, M.A. \& Kovacs, K.M. (2008) A simple new algorithm to filter marine mammal Argos locations. Marine Mammal Science, 24, 315-325.

Fretey J, (2000) Marine Turtles of the Atlantic Coast of Africa. UNEP/CMS Technical Publication No. 2 (Working document), $254 \mathrm{pp}$.

Gilman, E., Bianchi, G. \& Attwood, C. (2009) Guidelines to Reduce Sea Turtle Mortality in Fishing Operations. Food and Agriculture Organization of the United Nations, Rome.

Godley, B.J., Blumenthal, J.M., Broderick, A.C., Coyne, M.S., Godfrey, M.H., Hawkes, L.A., \& Witt, M.J. (2008) Satellite tracking of sea turtles: Where have we been and where do we go next? Endangered Species Research, 4, 3-22.

Gopi, G.V., Pandav, B. \& Choudhury, B.C. (2006) Incidental Capture and Mortality of Olive Ridley Turtles (Lepidochelys olivacea) in Commercial Trawl Fisheries in Coastal Waters of Orissa, India. Chelonian Conservation and Biology, 5, 276-280.

Graham, R.T., Witt, M.J., Castellanos, D.W., Remolina, F., Maxwell, S.M., Godley, B.J., \& Hawkes, L.A. (2012) Satellite tracking of manta rays highlights challenges to their conservation. PLoS ONE, 7, 7(5): e36834.

Hamel, M.A., McMahon, C.R. \& Bradshaw, C.J.A. (2008) Flexible inter-nesting behaviour of generalist olive ridley turtles in Australia. Journal of Experimental Marine Biology and Ecology, 359, 4754.

Hawkes, L.A., Broderick, A.C., Coyne, M.S., Godfrey, M.H., Lopez-Jurado, L.F., Lopez-Suarez, P., Merino, S.E., Varo-Cruz, N. \& Godley, B.J. (2006) Phenotypically linked dichotomy in sea turtle foraging requires multiple conservation approaches. Current Biology, 16, 990-995.

Hawkes, L.A., Witt, M.J., Broderick, A.C., Coker, J.W., Coyne, M.S., Dodd, M., Frick, M.G., Godfrey, M.H., Griffin, D.B., Murphy, S.R., Murphy, T.M., Williams, K.L. \& Godley, B.J. (2011) Home on the range: spatial ecology of loggerhead turtles in Atlantic waters of the USA. Diversity and Distributions, 17, 624-640.

Hays, G.C., Bradshaw, C.J., James, M.C., Lovell, P. \& Sims, D.W. (2007) Why do Argos satellite tags deployed on marine animals stop transmitting? Journal of Experimental Marine Biology and Ecology, 349, 52-60.

Hazen, E.L., Maxwell, S.M., Bailey, H., Bograd, S.J., Hamann, M., Gaspar, P., Godley, B.J. \& Shillinger, G.L. (2012) Ontogeny in marine tagging and tracking science: technologies and data gaps. Marine Ecology Progress Series, 457, 221-240.

Hijmans, R. J. \& Etten, J. (2012) raster: Geographic analysis and modelling with raster data. R package version 1.9-70.

Hobday, A.J., Hartog, J.R., Spillman, C.M. \& Alves, O. (2011) Seasonal forecasting of tuna habitat for dynamic spatial management. Canadian Journal of Fisheries and Aquatic Sciences, 68, 898-911.

Kappes, M.A., Shaffer, S.A., Tremblay, Y., Foley, D.G., Palacios, D.M., Robinson, P.W., Bograd, S.J. \& Costa, D.P. (2010) Hawaiian albatrosses track interannual variability of marine habitats in the North Pacific. Progress in Oceanography, 86, 246-260.

Lee, J., South, A.B. \& Jennings, S. (2010) Developing reliable, repeatable, and accessible methods to provide high-resolution estimates of fishing-effort distributions from vessel monitoring system (VMS) data. ICES Journal of Marine Science: Journal du Conseil, 67, 1260-1271.

Lewison, R.L., Crowder, L.B., Read, A.J. \& Freeman, S.A. (2004) Understanding impacts of fisheries bycatch on marine megafauna. Trends in Ecology \& Evolution, 19, 598-604. 
Lewison, R., Wallace, B.P., Alfaro-Shigueto, J., Mangel, J., Maxwell, S.M. \& Hazen, E.L. (2013) Fisheries bycatch of marine turtles: lessons learned from decades of research and conservation Biology of Sea Turtles, Volume 3 (ed. by J. Musick, K. Lohmann and J. Wyneken). pp. 329-352 CRC Press/Taylor \& Francis Group, Boca Raton FL.

Luschi, P., Hays, G.C. \& Papi, F. (2003) A review of long-distance movements by marine turtles, and the possible role of ocean currents. Oikos, 103, 293-302.

Marcovaldi, M.A. (1999) Status and distribution of the olive ridley turtle, Lepidochelys olivacea, in the Western Atlantic Ocean. Proceedings of the Regional Meeting, Marine Turtle Conservation in the Wider Caribbean Region: A Dialogue for Effective Regional Management, Santo Domingo (ed. by K.L. Eckert and F.A Abreu Grobois), pp. 52-56. WIDECAST, St. Croix, U.S. Virgin Islands.

Matthiopoulos, J., McConnell, B., Duck, C. \& Fedak, M. (2004) Using satellite telemetry and aerial counts to estimate space use by grey seals around the British Isles. Journal of Applied Ecology, 41, 476-491.

Maxwell, S.M., Breed, G.A., Nickel, B.A., Makanga-Bahouna, J., Pemo-Makaya, E., Parnell, R.J., Formia, A., Ngouessono, S., Godley, B.J., Costa, D.P., Witt, M.J. \& Coyne, M.S., (2011) Using satellite tracking to optimize protection of long-lived marine species: olive ridley sea turtle conservation in central Africa. PloS one, 6, e19905.

Maxwell, S.M., Frank, J.J., Breed, G.A., Robinson, P.W., Simmons, S.E., Crocker, D.E., Gallo-Reynoso, J.P. \& Costa, D.P. (2012) Benthic foraging on seamounts: A specialized foraging behavior in a deep-diving pinniped. Marine Mammal Science, 28, E333-E344.

McMahon, C.R., Bradshaw, C.J.. \& Hays, G.C. (2007) Satellite tracking reveals unusual diving characteristics for a marine reptile, the olive ridley turtle Lepidochelys olivacea. Marine Ecology Progress Series, 329, 239-252.

Pandav, B., Choudhury, B.C. \& Kar, C.S. (1997) Mortality of olive ridley turtles Lepidochelys olivacea due to incidental capture in fishing nets along the Orissa coast, India, Oryx, 31, 32-36.

Parnell, R., Verhage, B., Deem, S.J., Van Leeuwe, H., Nishihara, T., Moukoula, C. \& Gibudi, A. (2007) Marine turtle mortality in southern Gabon and northern Congo. Marine Turtle Newsletter, 116, $12-14$.

Peckham, S.H., Diaz, D.M., Walli, A., Ruiz, G., Crowder, L.B. \& Nichols, W.J. (2007) Small-Scale Fisheries Bycatch Jeopardizes Endangered Pacific Loggerhead Turtles. PloS one, 2, e1041.

Peterson, R.G. \& Stramma, L. (1991) Upper-level circulation in the South Atlantic Ocean. Progress in Oceanography, 26, 1-73.

Plotkin, P.T. (2010) Nomadic behaviour of the highly migratory olive ridley sea turtle Lepidochelys olivacea in the eastern tropical Pacific Ocean. Endangered Species Research, 13, 33-40.

Polovina, J.J., Kobayashi, D.R., Parker, D.M., Seki, M.P. \& Balazs, G.H. (2000) Turtles on the edge: movement of loggerhead turtles (Caretta caretta) along oceanic fronts, spanning longline fishing grounds in the central North Pacific, 1997-1998. Fisheries Oceanography, 9, 71-82.

Polovina, J.J., Howell, E., Parker, D.M. \& Balazs, G.H. (2003) Dive-depth distribution of loggerhead (Carretta carretta) and olive ridley(Lepidochelys olivacea) sea turtles in the Central North Pacific: Might deep longline sets catch fewer turtles? Fishery Bulletin, 101, 189-193.

Polovina, J.J., Balazs, G.H., Howell, E.A., Parker, D.M., Seki, M.P. \& Dutton, P.H. (2004) Forage and migration habitat of loggerhead (Caretta caretta) and olive ridley (Lepidochelys olivacea) sea turtles in the central North Pacific Ocean. Fisheries Oceanography, 13, 1-16.

R Development Core Team (2008) R: A language and environment for statistical computing. R Foundation for Statistical Computing, Vienna, Austria. ISBN 3-900051-07-0. http://www.Rproject.org.

Ram, P.S., Rao, S.A. \& Sadhuram, Y. (2009) Drifting and meandering of Olive Ridley Sea turtles in the Bay of Bengal: Role of oceanic Rossby waves. Marine Geodesy, 32, 372-378.

Rangel, T.F. \& Loyola, R.D. (2012) Labeling Ecological Niche Models. Natureza \& Conservação, 10, $119-126$. 
Rees, Al.F., Al-Kiyumi, A., Broderick, A.C., Papathanasopoulou, N. \& Godley, B.J. (2012) Conservation related insights into the behaviour of the olive ridley sea turtle Lepidochelys olivacea nesting in Oman. Marine Ecology Progress Series, 450, 195-205.

Roberts, J.J., Best, B.D., Dunn, D.C., Treml, E.A. \& Halpin, P.N. (2010) Marine Geospatial Ecology Tools: An integrated framework for ecological geoprocessing with ArcGIS, Python, R, MATLAB, and C++. Environmental Modelling \& Software, 25, 1197-1207.

Robinson, P.W., Costa, D.P., Crocker, D.E., Gallo-Reynoso, J.P., Champagne, C.D., Fowler, M.A., Goetsch, C., Goetz, K.T., Hassrick, J.L., Huckstadt, L.A., Kuhn, C.E., Maresh, J.L., Maxwell, S.M., McDonald, B.I., Peterson, S.H., Simmons, S.E., Teutschel, N.M., Villegas-Amtmann, S. \& Yoda, K. (2012) Foraging Behavior and Success of a Mesopelagic Predator in the Northeast Pacific Ocean: Insights from a Data-Rich Species, the Northern Elephant Seal. PloS one, 7, e36728.

Schofield, G., Hobson, V.J., Fossette, S., Lilley, M.K., Katselidis, K.A. \& Hays, G.C. (2010) Fidelity to foraging sites, consistency of migration routes and habitat modulation of home range by sea turtles. Diversity and Distributions, 16, 840-853.

Seminoff, J.A., Zárate, P., Coyne, M., Foley, D.G., Parker, D., Lyon, B.N. \& Dutton, P.H. (2008) Postnesting migrations of Galápagos green turtles Chelonia mydas in relation to oceanographic conditions: integrating satellite telemetry with remotely sensed ocean data. Endangered Species Research, 4, 57-72.

Shaffer, S.A., Tremblay, Y., Weimerskirch, H., Scott, D., Thompson, D.R., Sagar, P.M., Moller, H., Taylor, G.A., Foley, D.G., Block, B.A. \& Costa, D.P. (2006) Migratory shearwaters integrate oceanic resources across the Pacific Ocean in an endless summer. Proceedings of the National Academy of Sciences of the United States of America, 103, 12799-12802.

Shillinger, G.L., Palacios, D.M., Bailey, H., Bograd, S.J., Swithenbank, A.M., Gaspar, P., Wallace, B.P., Spotila, J.R., Paladino, F.V., Piedra, R., Eckert, S.A. \& Block, B.B.. (2008) Persistent leatherback turtle migrations present opportunities for conservation. PLoS Biology, 6, e171.

Silva, A.C.C.D., Santos, E.A.P., Oliveira, F.L.C., Weber, M.I., Batista, J.A.F., Serafini, T.Z. \& Castilhos, J.C. (2011) Satellite-tracking reveals multiple foraging strategies and threats for olive ridley turtles in Brazil. Mar Ecol Prog Ser, 443, 237-247.

Stewart, K.R., Lewison, R.L., Dunn, D.C., Bjorkland, R.H., Kelez, S., Halpin, P.N. \& Crowder, L.B. (2010) Characterizing fishing effort and spatial extent of coastal fisheries. PloS one, 5, e14451.

Sumner, M.D., (2011) trip: Spatial analysis of animal track data. R package version 1.1-10.

Thuiller, W., Lafourcade, B., Engler, R., Araújo, M.B. (2009) BIOMOD-a platform for ensemble forecasting of species distributions. Ecography 32, 369-373.

Thuiller, W., Georges, D. \& Engler, R. (2013) biomod2: Ensemble platform for species distribution modeling. R package version 2.1.7

Wallace, B.P., Lewison, R.L., McDonald, S.L., McDonald, R.K., Kot, C.Y., Kelez, S., Bjorkland, R.K., Finkbeiner, E.M. \& Crowder, L.B. (2010) Global patterns of marine turtle bycatch. Conservation Letters, 3, 131-142.

Weir, C.R., Ron, T., Morais, M. \& Duarte, A.D. (2007) Nesting and at-sea distribution of marine turtles in Angola, West Africa, 2000-2006: occurrence, threats and conservation implications. Oryx, 41, 224-231.

Weng, K.C., Boustany, A.M., Pyle, P., Anderson, S.D., Brown, A. \& Block, B.A. (2007) Migration and habitat of white sharks (Carcharodon carcharias) in the eastern Pacific Ocean. Marine Biology, 152, 877-894.

Whiting, S.D., Long, J.L. \& Coyne, M. (2007) Migration routes and foraging behaviour of olive ridley turtles Lepidochelys olivacea in northern Australia. Endangered Species Research, 3, 1-9.

Wingfield, D.K., Peckham, S.H., Foley, D.G., Palacios, D.M., Lavaniegos, B.E., Durazo, R., Nichols, W.J., Croll, D.A. \& Bograd, S.J. (2011) The making of a productivity hotspot in the coastal ocean. PloS one, 6, e27874.

Witt, M.J. \& Godley, B.J. (2007) A Step Towards Seascape Scale Conservation: Using Vessel Monitoring Systems (VMS) to Map Fishing Activity. PloS one, 2, e1111. 
Witt, M.J., Akesson, S., Broderick, A.C., Coyne, M.S., Ellick, J., Formia, A., Hays, G.C., Luschi, P., Stroud, S. \& Godley, B.J. (2010) Assessing accuracy and utility of satellite-tracking data using Argos-linked Fastloc-GPS. Animal Behaviour, 80, 571-581.

Witt, M.J., Bonguno, E.A., Broderick, A.C., Coyne, M.S., Formia, A., Gibudi, A., Mounguengui Mounguengui, G.A., Moussounda, C., NSafou, M., Nougessono, S., Parnell, R.J., Sounguet, G.P., Verhage, S. \& Godley, B.J. (2011) Tracking Leatherback Turtles from the World's Largest Rookery: Assessing Threats Across the South Atlantic. Proceedings of the Royal Society B: Biological Sciences, 278, 2338-2347.

Work, T.M. \& Balazs, G.H. (2002) Necropsy findings in sea turtles taken as bycatch in the North Pacific longline fishery. Fishery Bulletin 100, 876-880.

Zydelis, R., Lewison, R.L., Shaffer, S.A., Moore, J.E., Boustany, A.M., Roberts, J.J., Sims, M., Dunn, D.C., Best, B.D., Tremblay, Y., Kappes, M.A., Halpin, P.N., Costa, D.P. \& Crowder, L.B. (2011) Dynamic habitat models: using telemetry data to project fisheries bycatch. Proceedings of the Royal Society of London Series B-Biological Sciences, 278, 3191-3200.

\section{Biosketch}

Stephen K. Pikesley is a marine ecologist, whose work focuses on the integration and use of spatial ecological tools, including satellite tracking, remote sensing, GIS and habitat modelling to help identify and gain insight, into marine vertebrate spatial and temporal patterns and trends. This work constituted part of his doctoral thesis with MJW and BJG at the University of Exeter, working in the Marine Turtle Research Group (MTRG). Further information about the MTRG can be found at: http://www.seaturtle.org.uk/mtrg/.

\section{Statement of author contributions}

This work is the result of a major collaborative effort: SMM, KP, DPC, MSC, AF, BJG, WK, SM, SN, RJP, designed the experiments; SMM, KP, DPC, MSC, WK, JM-B, EP-M, collected data; SKP, MJW and BJG analysed the data, developed the manuscript and led the writing with contributions from all authors. 


\section{Supporting Information}

Table S1.

Summary of PTT data detailing nesting season, release site, and data start and end dates. Post-nesting periods, including track durations, are identified together with post-nesting turtle IDs and habitat classifications.

\begin{tabular}{|c|c|c|c|c|c|c|c|c|}
\hline $\begin{array}{l}\text { Release } \\
\text { site }\end{array}$ & ID & $\begin{array}{l}\text { Post-nesting } \\
\text { classification }\end{array}$ & $\begin{array}{l}\text { Nesting } \\
\text { season }\end{array}$ & $\begin{array}{l}\text { PTT } \\
\text { attachment } \\
\text { date }\end{array}$ & $\begin{array}{l}\text { Post- } \\
\text { nesting } \\
\text { start date }\end{array}$ & $\begin{array}{l}\text { Last } \\
\text { received } \\
\text { position }\end{array}$ & $\begin{array}{l}\text { Post- } \\
\text { nesting } \\
\text { tracking } \\
\text { duration } \\
\text { (days) }\end{array}$ & $\begin{array}{l}\text { Post- } \\
\text { nesting } \\
\text { tracking } \\
\text { distance } \\
\text { (km) }\end{array}$ \\
\hline Gabon & $\mathrm{A}$ & oceanic (within EEZ) & $2007 / 08$ & $30 / 10 / 2007$ & $30 / 11 / 2007$ & $10 / 01 / 2008$ & 41 & 1206 \\
\hline Gabon & $\mathrm{B}$ & coastal & 2008/09 & $23 / 10 / 2008$ & 07/01/2009 & 07/05/2009 & 120 & 787 \\
\hline Gabon & $\mathrm{C}$ & oceanic (within EEZ) & $2008 / 09$ & $12 / 11 / 2008$ & 04/12/2008 & 29/06/2009 & 207 & 3362 \\
\hline Gabon & $\mathrm{D}$ & oceanic (within EEZ) & 2008/09 & $13 / 11 / 2008$ & $03 / 12 / 2008$ & $20 / 09 / 2009$ & 291 & 6261 \\
\hline Gabon & $\mathrm{E}$ & oceanic (within EEZ) & $2008 / 09$ & $14 / 11 / 2008$ & $18 / 11 / 2008$ & $10 / 03 / 2009$ & 112 & 1985 \\
\hline Gabon & F & oceanic (within EEZ) & $2008 / 09$ & $14 / 11 / 2008$ & $05 / 12 / 2008$ & $16 / 08 / 2009$ & 254 & 4582 \\
\hline Gabon & G & oceanic (within EEZ) & $2008 / 09$ & $15 / 11 / 2008$ & $12 / 12 / 2008$ & 01/02/2009 & 51 & 1337 \\
\hline Gabon & $\mathrm{H}$ & oceanic (within EEZ) & 2008/09 & $15 / 11 / 2008$ & $10 / 12 / 2008$ & 04/03/2009 & 84 & 1149 \\
\hline Gabon & I & oceanic (within EEZ) & 2008/09 & $16 / 11 / 2008$ & $14 / 12 / 2008$ & $16 / 01 / 2009$ & 33 & 694 \\
\hline Gabon & $\mathrm{J}$ & oceanic (within EEZ) & $2008 / 09$ & $19 / 12 / 2008$ & $23 / 01 / 2009$ & $27 / 02 / 2009$ & 35 & 730 \\
\hline Gabon & $\mathrm{K}$ & oceanic (within EEZ) & $2008 / 09$ & $19 / 11 / 2008$ & $28 / 12 / 2008$ & $09 / 07 / 2009$ & 193 & 3505 \\
\hline Gabon & $\mathrm{L}$ & oceanic (within EEZ) & $2008 / 09$ & $19 / 11 / 2008$ & $05 / 12 / 2008$ & $14 / 04 / 2010$ & 495 & 9182 \\
\hline Angola & M & oceanic (within EEZ) & $2008 / 09$ & $19 / 11 / 2008$ & $22 / 12 / 2008$ & $24 / 03 / 2009$ & 92 & 1537 \\
\hline Angola & $\mathrm{N}$ & oceanic (within EEZ) & $2008 / 09$ & $21 / 11 / 2008$ & $30 / 11 / 2008$ & $24 / 01 / 2009$ & 55 & 904 \\
\hline Angola & $\mathrm{O}$ & oceanic (within EEZ) & $2008 / 09$ & $26 / 11 / 2008$ & $29 / 12 / 2008$ & 05/07/2009 & 188 & 2416 \\
\hline Angola & $\mathrm{P}$ & oceanic (within EEZ) & $2008 / 09$ & 03/12/2008 & $04 / 12 / 2008$ & $13 / 03 / 2009$ & 98 & 1305 \\
\hline Angola & Q & oceanic (within EEZ) & $2008 / 09$ & $03 / 12 / 2008$ & $28 / 12 / 2008$ & $19 / 04 / 2009$ & 111 & 2199 \\
\hline Angola & $\mathrm{R}$ & oceanic (within EEZ) & 2008/09 & $14 / 12 / 2008$ & $24 / 12 / 2008$ & $10 / 11 / 2010$ & 686 & 6880 \\
\hline Angola & $S$ & oceanic (within EEZ) & 2008/09 & $11 / 01 / 2009$ & $13 / 01 / 2009$ & 07/04/2009 & 84 & 2769 \\
\hline Angola & $\mathrm{T}$ & oceanic (outside EEZ) & $2009 / 10$ & 05/05/2009 & 07/11/2009 & 01/03/2010 & 114 & 2710 \\
\hline Angola & $\mathrm{U}$ & oceanic (outside EEZ) & $2009 / 10$ & 05/05/2009 & $22 / 11 / 2009$ & $13 / 05 / 2010$ & 172 & 1572 \\
\hline
\end{tabular}


Table S2.

Ecological Niche Modelling evaluation metrics for 10 fold cross validation. Algorithm abbreviations: Generalized Additive Model (GAM), Multivariate Adaptive Regression Splines (MARS) and Maximum Entropy (MaxEnt). Key algorithm modelling parameters and evaluation metric descriptions are detailed at the foot of the table.

\begin{tabular}{lllllllll}
\hline Evaluation metric & Ru & \multicolumn{3}{c}{ Modelling algorithm } & Ru & \multicolumn{3}{c}{ Modelling algorithm } \\
& $\mathbf{n}$ & GAM & MARS & MaxEn & $\mathbf{n}$ & GAM & MARS & MaxEn \\
& & & & $\mathbf{t}$ & & & & $\mathbf{t}$ \\
\hline AUC & $\mathbf{1}$ & 0.95 & 0.95 & 0.95 & $\mathbf{6}$ & 0.95 & 0.95 & 0.95 \\
KAPPA & & 0.78 & 0.78 & 0.78 & & 0.78 & 0.76 & 0.78 \\
TSS & & 0.79 & 0.80 & 0.79 & & 0.79 & 0.78 & 0.79 \\
SR & & 0.98 & 1.00 & 0.97 & & 0.99 & 0.96 & 1.00 \\
Accuracy & & 0.89 & 0.89 & 0.89 & & 0.89 & 0.88 & 0.89 \\
& & & & & & & & \\
AUC & $\mathbf{2}$ & 0.95 & 0.95 & 0.95 & 7 & 0.96 & 0.95 & 0.95 \\
KAPPA & & 0.79 & 0.80 & 0.79 & & 0.81 & 0.80 & 0.80 \\
TSS & & 0.80 & 0.81 & 0.81 & & 0.82 & 0.81 & 0.81 \\
SR & & 0.99 & 0.94 & 0.97 & & 1.00 & 0.98 & 0.98 \\
Accuracy & & 0.89 & 0.90 & 0.89 & & 0.90 & 0.90 & 0.90 \\
& & & & & & & & \\
AUC & $\mathbf{3}$ & 0.96 & 0.96 & 0.95 & $\mathbf{8}$ & 0.95 & 0.95 & 0.95 \\
KAPPA & & 0.79 & 0.79 & 0.80 & & 0.79 & 0.77 & 0.78 \\
TSS & & 0.81 & 0.81 & 0.81 & & 0.80 & 0.78 & 0.79 \\
SR & & 1.00 & 0.98 & 1.00 & & 0.97 & 0.97 & 0.97 \\
Accuracy & & 0.90 & 0.90 & 0.90 & & 0.90 & 0.89 & 0.89 \\
& & & & & & & & \\
AUC & $\mathbf{4}$ & 0.96 & 0.96 & 0.95 & $\mathbf{9}$ & 0.95 & 0.95 & 0.95 \\
KAPPA & & 0.80 & 0.81 & 0.79 & & 0.79 & 0.79 & 0.79 \\
TSS & & 0.81 & 0.82 & 0.80 & & 0.80 & 0.81 & 0.80 \\
SR & & 1.00 & 0.99 & 0.99 & & 1.00 & 0.98 & 0.98 \\
Accuracy & & 0.90 & 0.91 & 0.90 & & 0.90 & 0.90 & 0.90 \\
AUC & & & & & & & \\
KAPPA & $\mathbf{5}$ & 0.95 & 0.95 & 0.95 & $\mathbf{1 0}$ & 0.95 & 0.94 & 0.95 \\
TSS & & 0.78 & 0.76 & 0.78 & & 0.77 & 0.78 & 0.78 \\
SR & & 0.79 & 0.78 & 0.79 & & 0.79 & 0.80 & 0.79 \\
Accuracy & 0.99 & 0.96 & 1.00 & & 1.00 & 0.97 & 0.99 \\
& & 0.89 & 0.88 & 0.89 & & 0.89 & 0.89 & 0.89 \\
& & mean & of means & evaluation score & $\mathbf{0 . 8 8 5}$ & $\mathbf{0 . 8 8 0}$ & $\mathbf{0 . 8 8 2}$ \\
& standard deviation of the mean & $\mathbf{0 . 0 0 7}$ & $\mathbf{0 . 0 1 0}$ & $\mathbf{0 . 0 0 5}$ \\
\hline
\end{tabular}

biomod2 modelling parameters.

One set of 5000 randomly generated 'pseudo absence' locations (background data), with no minimum or maximum distance to presence locations were generated. All locations that had missing coincident environmental data were removed from the analysis (background data locations that were spatially referenced on land). Total background data locations used in analysis : $n=4175$.

The algorithm modelling parameters in biomod2 were as follows:

GAM: package = 'mgcv', family = 'binomial', type = 's' (spline based smooth).

MARS: package $=$ 'mda', maximum interaction degree $=2$, penalty $($ cost per degree of freedom $)=2$, thresh (forward stepwise stopping threshold) $=0.001$, prune $=($ TRUE) . 
MaxEnt: Run within biomod2, maximum iterations (for training) $=200$,

linear/quadratic/product/threshold/ hinge features (the transformation coefficients applied to each environmental variable), default prevalence $=0.5$.

Evaluation metrics:

AUC (Area under the curve): a measure of the ratio of true positives out of the positives vs. the ratio of false positives out of the negatives.

KAPPA (Cohen's Kappa, Heidke skill score) and TSS (True Skill Statistic): measures of accuracy relative to that of random chance.

SR (Success Ratio): the fraction of the true positives that were correct.

Accuracy (fraction correct): the fraction of the predictions (true and false) that were correct. 
Table S3.

Summary of Angolan marine fisheries gear types and fisheries zones (FAO, 2007)

\begin{tabular}{lll}
\hline Fishery & Fishing gear & Fisheries zone \\
\hline Pelagic & Trawl, seine & Whole coast, but mostly southern zone \\
& Purse seine & Whole coast, but mostly central and northern zones \\
& Longline & Whole coast \\
Demersal & Trawl, gillnet & Whole coast \\
Crustaceans & Trawl & Central zone \\
& Trap & Central and southern zones \\
\hline
\end{tabular}

Approximate latitudinal banding of fisheries zones:

Northern zone: Cabinda to Luanda ( $\mathrm{S} 5^{\circ}$ to $\mathrm{S} 9.25^{\circ}$ )

Central zone: Luanda to Benguela/Lobito (S $9.25^{\circ}$ to $\left.\mathrm{S} 13^{\circ}\right)$

Southern zone: Benguela/Lobito to the Cunene River ( $\mathrm{S} 13^{\circ}$ to $\mathrm{S} 17.25^{\circ}$ ) 
Table S4.

Cumulative tuna and billfish catch data (1995-2009) by FAO Major Fishing Area Cell (FAO, 2012a; $2012 \mathrm{~b}$ ) at $5^{\circ}$ by $5^{\circ}$ resolution. These data were apportioned for the cell's coincident sea area , by fisheries zone and gear type. Source data: http://www.fao.org/figis/geoserver/tunaatlas/

\begin{tabular}{|c|c|c|c|c|c|c|c|c|}
\hline \multirow[b]{3}{*}{$\begin{array}{l}\text { Fisheri } \\
\text { es zone }\end{array}$} & \multicolumn{8}{|c|}{ Cumulative tuna and billfish catches by fisheries gear (1995-2009) } \\
\hline & \multicolumn{2}{|l|}{ longline } & \multicolumn{2}{|l|}{ purse seine } & \multicolumn{2}{|c|}{ other gear } & \multicolumn{2}{|l|}{ all gear } \\
\hline & $\begin{array}{l}\text { tonnes/k } \\
\text { m }^{2}\end{array}$ & $\begin{array}{l}\% \text { of } \\
\text { total }\end{array}$ & tonnes $/ \mathrm{km}^{2}$ & $\begin{array}{l}\% \text { of } \\
\text { total }\end{array}$ & $\begin{array}{l}\text { tonnes/k } \\
\mathbf{m}^{2}\end{array}$ & $\begin{array}{l}\% \text { of } \\
\text { total }\end{array}$ & $\begin{array}{l}\text { tonnes/k } \\
\mathbf{m}^{2}\end{array}$ & $\begin{array}{c}\text { \% by } \\
\text { zone }\end{array}$ \\
\hline $\begin{array}{l}\text { Northe } \\
\text { rn }\end{array}$ & 0.07 & 12.7 & 0.22 & 40.0 & 0.01 & 1.8 & 0.30 & 55 \\
\hline $\begin{array}{l}\text { Centra } \\
\text { l }\end{array}$ & 0.05 & 9.1 & 0.09 & 16.3 & 0.02 & 3.6 & 0.16 & 29 \\
\hline $\begin{array}{l}\text { Southe } \\
\text { rn }\end{array}$ & 0.06 & 10.9 & 0.02 & 3.6 & 0.01 & 1.8 & 0.09 & 16 \\
\hline & & & & & Tota & all gear & 0.55 & \\
\hline
\end{tabular}


Table S5.

Ecological Niche Modelling variable importance for 10 fold cross validation.

\begin{tabular}{|c|c|c|c|c|c|c|c|c|c|c|c|c|}
\hline Model & Run & Depth & $\begin{array}{l}\text { Dist. } \\
\text { to } \\
\text { front }\end{array}$ & NPP & SSH & SST & Run & Depth & $\begin{array}{l}\text { Dist. } \\
\text { to } \\
\text { front }\end{array}$ & NPP & SSH & SST \\
\hline GAM & 1 & 0.03 & 0.44 & 0.05 & 0.20 & 0.29 & 6 & 0.03 & 0.44 & 0.05 & 0.20 & 0.29 \\
\hline MARS & & 0.00 & 0.54 & 0.15 & 0.20 & 0.11 & & 0.00 & 0.56 & 0.11 & 0.17 & 0.15 \\
\hline MaxEnt & & 0.04 & 0.44 & 0.18 & 0.17 & 0.18 & & 0.06 & 0.44 & 0.17 & 0.15 & 0.18 \\
\hline $\begin{array}{l}\text { mean var. } \\
\text { imp. }\end{array}$ & & 0.02 & 0.47 & 0.13 & 0.19 & 0.19 & & 0.03 & 0.48 & 0.11 & 0.18 & 0.21 \\
\hline GAM & 2 & 0.03 & 0.44 & 0.05 & 0.20 & 0.29 & 7 & 0.03 & 0.44 & 0.05 & 0.20 & 0.29 \\
\hline MARS & & 0.00 & 0.40 & 0.22 & 0.25 & 0.13 & & 0.00 & 0.50 & 0.19 & 0.20 & 0.11 \\
\hline MaxEnt & & 0.06 & 0.42 & 0.18 & 0.16 & 0.18 & & 0.05 & 0.45 & 0.18 & 0.16 & 0.17 \\
\hline $\begin{array}{l}\text { mean var. } \\
\text { imp. }\end{array}$ & & 0.03 & 0.42 & 0.15 & 0.20 & 0.20 & & 0.02 & 0.46 & 0.14 & 0.18 & 0.19 \\
\hline GAM & 3 & 0.03 & 0.44 & 0.05 & 0.20 & 0.29 & 8 & 0.03 & 0.44 & 0.05 & 0.20 & 0.29 \\
\hline MARS & & 0.00 & 0.54 & 0.13 & 0.18 & 0.15 & & 0.00 & 0.50 & 0.24 & 0.22 & 0.04 \\
\hline MaxEnt & & 0.06 & 0.43 & 0.18 & 0.15 & 0.18 & & 0.04 & 0.42 & 0.19 & 0.16 & 0.19 \\
\hline $\begin{array}{l}\text { mean var. } \\
\text { imp. }\end{array}$ & & 0.03 & 0.47 & 0.12 & 0.18 & 0.21 & & 0.02 & 0.45 & 0.16 & 0.19 & 0.17 \\
\hline GAM & 4 & 0.03 & 0.44 & 0.05 & 0.19 & 0.30 & 9 & 0.03 & 0.44 & 0.05 & 0.19 & 0.29 \\
\hline MARS & & 0.00 & 0.53 & 0.13 & 0.18 & 0.15 & & 0.00 & 0.50 & 0.13 & 0.28 & 0.09 \\
\hline MaxEnt & & 0.05 & 0.43 & 0.18 & 0.16 & 0.18 & & 0.05 & 0.41 & 0.19 & 0.17 & 0.18 \\
\hline $\begin{array}{l}\text { mean var. } \\
\text { imp. }\end{array}$ & & 0.03 & 0.47 & 0.12 & 0.18 & 0.21 & & 0.03 & 0.45 & 0.12 & 0.21 & 0.19 \\
\hline GAM & 5 & 0.03 & 0.44 & 0.05 & 0.20 & 0.29 & 10 & 0.03 & 0.44 & 0.05 & 0.20 & 0.29 \\
\hline MARS & & 0.01 & 0.53 & 0.17 & 0.21 & 0.08 & & 0.00 & 0.52 & 0.19 & 0.19 & 0.10 \\
\hline MaxEnt & & 0.06 & 0.44 & 0.17 & 0.15 & 0.18 & & 0.06 & 0.42 & 0.18 & 0.16 & 0.19 \\
\hline mean var. & & 0.03 & 0.47 & 0.13 & 0.19 & 0.18 & & 0.03 & 0.46 & 0.14 & 0.18 & 0.19 \\
\hline & & & \multirow{2}{*}{\multicolumn{5}{|c|}{$\begin{array}{r}\text { mean of means variable importance } \\
\text { standard deviation of the mean }\end{array}$}} & 0.027 & 0.461 & 0.131 & 0.188 & 0.193 \\
\hline & & & & & & & & 0.003 & 0.016 & 0.014 & 0.012 & 0.011 \\
\hline
\end{tabular}

Relative importance of the contribution of an environmental variable is calculated using a randomisation process. This procedure calculates the correlation between a prediction using all environmental variables and a prediction where the independent variable being assessed is randomly re-ordered. If the correlation is high the variable in question is considered not important for the model and conversely, if low, important. A mean correlation coefficient for each environmental variable is then calculated over multiple runs. This is repeated for each environmental variable. The calculation of the relative importance is made by subtracting these mean correlation coefficient from 1 (Thuiller et al., 2009 ). 
Table S6.

Gear modifications and adjustment to fisheries practice to reduce turtle bycatch (Gilman et al., 2009)

\begin{tabular}{ll}
\hline Fishery & Principal mitigation measures \\
\hline Pelagic longlines and bottom set longlines & Use circle hooks \\
& Set hooks deeper avoiding the upper water column* \\
& Reduce gear soak time \\
& Use fish as bait, not squid \\
& Single hook bait, do not thread hook through the bait \\
& Avoid encircling turtles \\
& Monitor Fish Aggregating Devices (FADs) \\
Purse seine & Recover FADs when not in use \\
& Modify FADs to reduce/eliminate entanglement risk \\
& Use Turtle Excluder Devices (TEDs) \\
Trawl & Set nets perpendicular to the shore to reduce interactions \\
Set gillnets and drifting gillnets & with nesting females \\
& Set nets deeper, avoid the upper water column \\
& Use low profile nets \\
& Eliminate the use of 'tie-down' ropes \\
\hline
\end{tabular}

* There is the potential for the interaction rate to be much lower with deeper set nets, although the mortality rate for those turtles that are caught is higher 
Fig. S1.

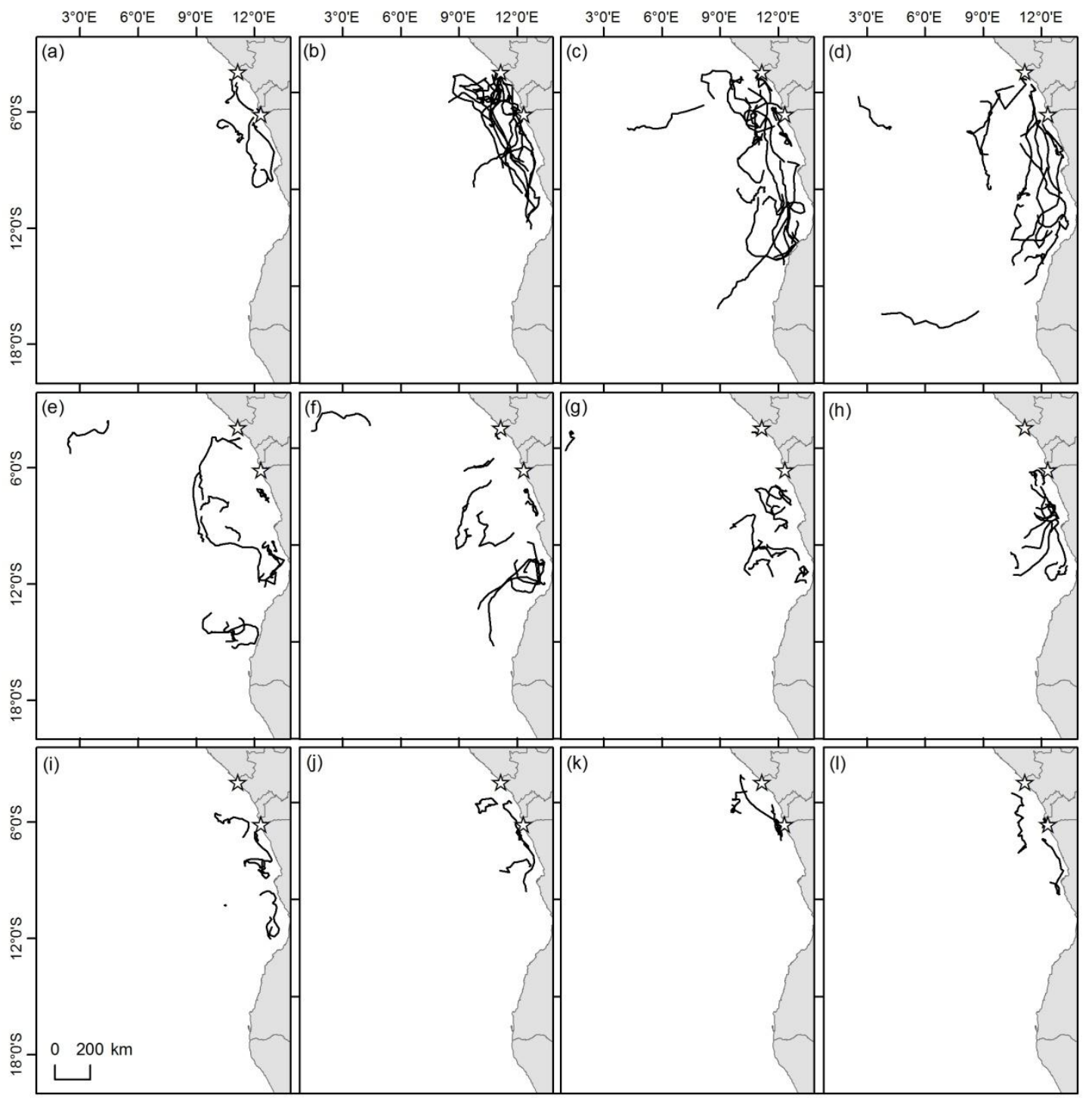

Fig. S1. Monthly satellite tracked post-nesting movements for olive ridley turtles derived from noninterpolated, best daily locations. Months are ordered from November (a: top left) to October (1: bottom right). Month order was determined by the start of turtle post-nesting activity. The release sites for tagged turtles are shown as open stars. 
Fig. S2.
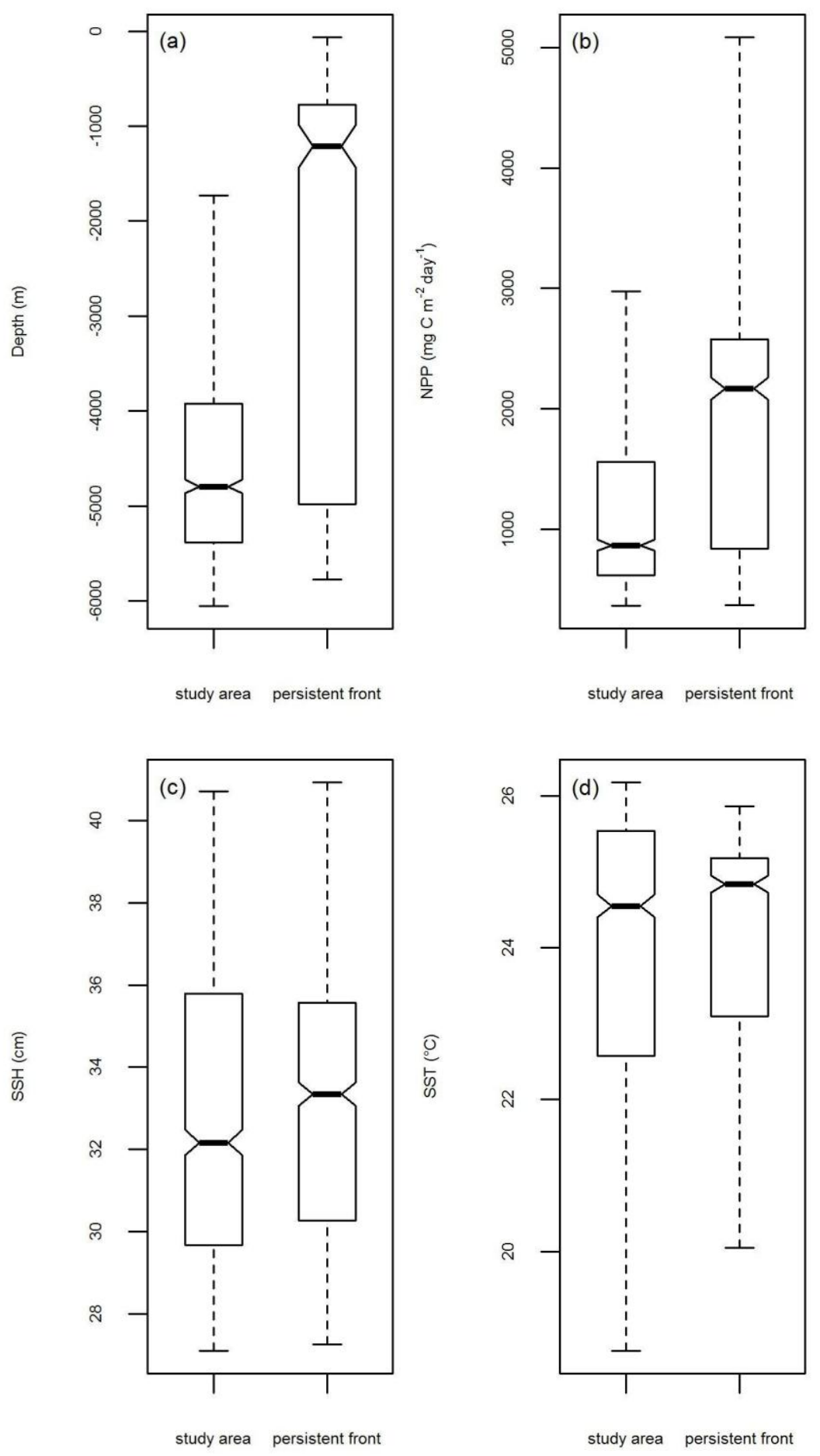

Fig. S2. Median and inter-quartile ranges for (a) depth (m), (b) NPP $\left(\mathrm{mg} \mathrm{C} \mathrm{m}^{-2} \mathrm{day}^{-1}\right)$, (c) SSH (cm) and (d) SST $\left({ }^{\circ} \mathrm{C}\right.$ ) for areas of persistent frontal activity (sample $n=887$ ) and the entire study area (sample $n=$ $1,000)$. 